\title{
A Critical Overview of Teaching English to Speakers of Other Languages
}

\author{
Simhachalam Thamarana \\ Research Scholar, Department of English \\ Andhra University, Visakhapatnam \\ Andhra Pradesh \\ thamarana.simhachalam@gmail.com
}

\author{
Prof. T. Narayana \\ Professor, Department of English \\ Andhra University, Visakhapatnam \\ Andhra Pradesh \\ narayana_t123@rediffmail.com
}

\begin{abstract}
A brief introduction to English Language Teaching related terminology such as EFL, ESP, TEAL, EAP, EOP etc. is to be critically examined at the outset. The concept of 'Learner Centred Language Teaching' and various methodology of teaching are to be presented at a glance. Some critical discussion on various methods like Grammar Translation, Audio-lingual, CLT and Task Based Language Teaching is to be done. Most importantly, teaching of various language skills i.e. LSRW along with some essential components related to these major language skills are to be presented. For instance, various concepts related to these LSRW skills such as scaffolding, receptive and productive language skills, top-down and bottom-up listening. 'Speaking skill' development can be achieved through various speaking tasks including role-plays, information gaps, simulations etc. Further, some important reading models such as bottom-up, top-down, interactive processing along with extensive and intensive reading are to be critically examined. Teaching of writing skill involves certain principles, approaches such as 'product' and 'process'. Finally the conclusions are drawn by means of the review of literature indicated.
\end{abstract}

Keywords: Language Teaching, Foreign Language, Mother Tongue, Second Language, LSRW.

\section{INTRODUCTION}

Some recurrent terminology related to English Language Teaching such as EFL, ESP, TEAL, EAP, EOP have stood for certain implications. EFL (English as a Foreign Language) refers to English language is taught in a country whose first language is not English where as Teaching English in an English speaking country is called as ESL (English as a Second Language) Teaching English as an additional language (TEAL) can be sometimes as ESP (English for Specific Purposes), EAP (English for Academic Purposes), EOP (English for Occupational Purposes). Most of the terminology can be covered under the label TESOL (Teaching English for Speakers of Other Languages). In English language teaching, use of various terms such as 'foreign language', 'second language', 'bilingualism', 'language learning', and 'language acquisition' are to be understood with certain implications. We can classify any languages into certain groups on the basis of subjective relationship between a language and a group or an individual; or on the objective relationship just without reference to relationship of individuals to a particular language. H.H. Stern in his, Fundamental Concepts of Language Teaching tabulated two sets of terms related to a language as follows:

\begin{tabular}{|c|c|}
\hline L1 & L2 \\
\hline First language & Second language \\
\hline Native language & Non-native language \\
\hline Mother tongue & Foreign language \\
\hline Primary language & Secondary language \\
\hline Stronger language & Weaker language \\
\hline
\end{tabular}

\section{Methodology and 'Learner Centred Language Teaching}

Methodology of teaching fits into the larger picture of curriculum development and it has three important subcomponents to curriculum development i.e. Syllabus design, Methodology, and Evaluation. These three components should have harmony with one another. So, methodology should be interconnected to the syllabus, and evaluation, assessment that should also be focused on teaching and learning equally. The terms 'learner centeredness', 'autonomy', 'self-direction' are mostly related to learner-centered approach to language instruction. The concept of learner-centeredness is not 
difficult to understand. However, it can be difficult to implement in the classroom. In a learnercentered classroom, learning experiences are related to learners' own out-of-class experiences. According to David Pearson, a famous American psychologist, learning is a building bridges what we already know and what we need to know. So in this kind of classroom, learners take responsibility and they are engaged in their own learning. The learners participated in making decisions related to content of learning, approaches to learning and involves in various assessments. There are two sets of goals in this kind of classrooms such as language goals and learning goals to make learner superfluous. In 1960s Chomskyan models of first language acquisition considered children as the creators of their own languages which led to Second Language Acquisition research concentrating on learner as the central element in the learning situation.

\section{The Four Major Language SkILlS}

${ }^{5}$ Most of the language learning and teaching strategies are intended to achieve necessary skills like Listening, Speaking, Reading and Writing (p. 76). Teaching of these major language skills are essential components of language proficiency along with some related skills such 'study' and 'reference' skills. $\mathrm{H}$. H. Stern expressed the necessity of gaining additional skills to Listening, Speaking, Reading and Writing skills in his Fundamental Concepts of Language Teaching that "Since the sixties it has become increasingly clear that a simple classification of proficiency as the 'four skills' of listening, speaking, reading, and writing, is inadequate, particularly for curriculum development and testing" and he also reminded that "A great deal of work has been done over the past two decades to offer teachers, testers, and researchers theoretically more clearly defined, descriptively more differentiated, and practically more serviceable specifications of language proficiency" (Stern p. 347). There is a great need of teaching some important minor skills too such as "pronunciation which deals with two interrelated skills - recognition or understanding the flow of speech, and production or fluency in the spoken language" (Broughton and Brumfit et al p. 49) and it is also clearly stated that "it is only practice in listening and speaking which will give the learner the skills he requires" (Broughton and Brumfit et al p. 49). Some skills can be called as 'receptive' and some as 'productive' skills. So listening and reading with understanding are receptive, decoding skills where as speaking and writing are productive, encoding skills; further "there is much in common between the receptive skills of listening and reading, and the productive skills of speaking and writing". There is a need of certain capabilities for reading and understanding a text on a paper and "it is impossible to learn to read without at least the capacity to acquire language" (Broughton and Brumfit et al p. 90). One can follow an integrated approach in teaching of four major language skills i.e. LSRW in conjunction with each other, as when a lesson involves activities that relate listening and speaking to reading and writing.

\section{TEAChING LiSTENING SKILL}

Most importantly, language laboratories are closely associated with the audio-lingual method and these laboratories have been replaced in many institutions by a multi-media laboratory in present days. Teaching listening skill involves the role of individual linguistic units such as phonemes, words, grammatical structures and the role of the listener's expectations, situation, context, background knowledge and the topic. It may include both top-down processing and bottom-up processing. Listening comprehension activities typically address a number of listening functions, including recognition, orientation, comprehension of main ideas, and understanding and recall of details. So many recent approaches emphasize the role of listening in building up language competence and suggest that more attention should be paid to teaching listening in the initial stages of foreign language learning. Use of pre-listening activities are very useful in preparing students for listening and so these activities may pre-teach vocabulary, turn on background knowledge, predict content, check ideas and understanding of a topic. According to Krashen's theory of language acquisition, comprehensible input involves a spoken language that can be understood by the listener even though some structures and vocabulary may not be known. It is a necessary condition for second language acquisition. Active listeners show their understanding of what a speaker says by repeating what the speaker has said or by responding in other ways to show comprehension where as auditory learners learn by listening, rather than learning in some other way. Both these active and auditory learners use right ear advantage. Learners need to activate relevant schemata allowing them to process and interpret new experiences quickly and efficiently and the schemata plays an important role in theories of second language reading and listening comprehension. But kinaesthetic learners learn through carrying out physical activities. Another technique for listening can be used to study how the brain controls hearing and language that is dichotic listening. In this kind of listening, first the subjects wear 
earphones and receive different sounds in both the ears then they are asked to repeat what they hear. In this process, the ability to perceive language better in the right ear than the left ear is called a 'right-ear advantage' and the ability to perceive language better in the left ear is called 'left-ear advantage'.

Gist listening is also known as listening for global understanding in order to get the main ideas of a listening passage where as listening for details is to understand the specific information contained in a text, which is similar to selective listening. ${ }^{5} \mathrm{~A}$ strategy is - procedures used in learning, thinking, etc., which serve as a way of reaching a goal (page 75). Selective listening is a strategy, whereby students are usually asked to attend to specific information that has been signalled prior to listening activity. Some listeners may have acoustic filtering ability for specific sounds in a speech. In order to help students to learn to distinguish a sound contrast 'minimal pair drill' is useful. For instance, if a teacher wanted to practise the contrast between $/ \mathrm{b} /$ and $/ \mathrm{p} /$ the teacher could explain how the sounds differ; the teacher could present pairs of words containing the contrast, for listening practice, for example: bore pour, big - pig, buy - pie. It is also to show that students know which member of the pair they have heard and get them to pronounce such pairs themselves.

\section{Teaching SPEaking SkILl}

'Speaking skill' development can be achieved through various speaking tasks including role-plays, information gaps, simulations etc. Role playing is a drama-like classroom activities in which students assume the roles of different participants in a imagined situation and act out what might typically happen in that situation. For instance, to practise how to express requests and gratitude in a foreign language, students might have to role-play a situation in which a passenger in a rail station asks for a journey ticket to a particular place and expresses his thanks to the ticket booking officer. Some speech events/speech situations are very useful to develop speaking skill such as an exchange of greetings, an enquiry and a conversation etc. Some main components of a speech event are its setting, the participants and their role relationships, the message, the key and the channel. Speech accent is a particular way of speaking which tells the listener something about the speaker's background in terms of the region or the country, the social class and whether he/she is a native speaker of the language. Teacher may use simpler words and sentence structures to accommodate when he/she is talking to a class of young children which is called convergence. Alternatively a person may exaggerate their rural accent because they are annoyed by the attitude of someone from the city is called divergence. ${ }^{5}$ For learning of each and every language skill, we need to have specific and apt learning strategy (p. 76). Convergence is a strategy in which people adapt to each other's speech by adjusting such things as speech rate, pauses, length of utterance, and pronunciation. In speaking activity, communicative competence is a significant aspect. It includes various other competences such as grammatical competence, sociolinguistic competence, discourse competence, strategic competence etc.

\section{Teaching Reading SKILL}

Teaching of reading skill is intended to understand a written text. Reading comprehension is the result of an understanding of text. Involvement of many cognitive skills in reading activity is essential such as letter and word recognition, knowledge of syntax, and recognition of text types and text structure etc. Most importantly there are two kinds of processes involved in reading comprehension, such as comprehension that is based on clues in the text is referred to as 'bottom-up processing' and comprehension that makes use of information outside of the text is known as 'top-down processing'. There are different types of reading comprehension often distinguished according to the reader's purposes in reading and the type of reading used. Literal comprehension intended to understand, remember and recall the information contained in a text; inferential comprehension intended to find information by inferencing or by intuition; critical comprehension is intended for comparison where as appreciative comprehension for gaining an emotional or valued responses from a textual passage. There are some useful pre-reading activities help in introduction of vocabulary, activate necessary background knowledge, activating reading strategies, predicting content, checking ideas and understanding of a topic. In addition to these activities, use of some micro-skills in reading is certainly advantages in terms of recognizing words, identifying grammatical functions of words, noticing specific details, making inferences, making comparisons and making predictions.

The reading speed which a person does follow is depended on various things such as the type of reading material, the reader's purpose, the level of comprehension required and the reader's individual reading skills. The following table shows some usual reading speeds of a good reader: 


\begin{tabular}{|c|c|c|}
\hline Speed & Purpose & good reader \\
\hline Slow & $\begin{array}{c}\text { Study reading, used when material is difficult } \\
\text { and/or high comprehension is required }\end{array}$ & $\begin{array}{c}200-300 \text { words per minute (wpm) } \\
80-90 \% \text { comprehension }\end{array}$ \\
\hline Average & Used for everyday reading of magazines, \\
newspapers, etc. & $\begin{array}{c}250-500 \mathrm{wpm} \\
70 \% \text { comprehension }\end{array}$ \\
\hline \multirow{2}{*}{ Fast } & $\begin{array}{c}\text { Skimming, used when highest speed is required } \\
\text { and comprehension is intentionally lower }\end{array}$ & $\begin{array}{c}800+\text { wpm } \\
50 \% \text { comprehension }\end{array}$ \\
\hline
\end{tabular}

There are many reading strategies, tasks, techniques such as scanning, skimming, extensive reading, intensive reading, reading for details, content reading, critical reading, word by word reading, guided reading, sub-vocal reading, sustained silent reading, paced reading, interactive reading etc. Scanning is used when the reader wants to locate a particular piece of information without necessarily comprehending the rest of a passage where as in skimming the reader samples segments of a text in order to achieve a general understanding of its meaning. An alphabetic method is a method of teaching to read in a mother tongue. Sometimes loss of the ability to use language due to brain damage is called as aphasia, that loss may be total or partial which affects spoken or written language abilities. Different kinds of aphasia are: 'agraphia' is difficulty in writing; alexia is difficulty in reading; 'anomia' is difficulty in using proper nouns; and 'agrammatism' is difficulty in using grammatical words like prepositions, articles and others. There is an extensive reading programme called 'book flood' to develop reading skills particularly in the settings where English is a second language, in which students are exposed to a large number of high-interest reading materials. In a cloze test, measuring reading comprehension and overall language proficiency are intended. Words are deleted from a reading passage at regular intervals, leaving blanks and there are two widely used ways to create the blanks. The first is known as rational deletion, where words are deleted on the basis of some rational decision which results in rational cloze. For example, articles may be deleted to assess test takers' knowledge of English articles. The second is known as fixed ratio deletion or nth word deletion, where every nth word is deleted. For example, every fifth word may be deleted. The test taker must then read the passage and try to guess the missing words.

\section{Teaching Writing SKILL}

Teaching of writing in any language is involved with a system of written symbols which represent the sounds, syllables, or words of a language. The three main types of writing system are alphabetic based on sounds; syllabic - based on syllables; and ideographic - based on words. Further, teaching of writing skill includes many things such as mechanics of writing, composition, editing, revising etc. There are different stages involved in writing as follow:

- 'Prewriting' is involved with various activities in which writers look for a topic or for ideas and language related to a topic before beginning writing. It is also known as rehearsing.

- 'Writing' is involved with various activities in which writers note down ideas in rough form. It is also known as planning, drafting or composing stage.

- 'Revising' is involved with various activities in which writers check, revise and rewrite what they have written. These stages in writing do not necessarily occur in sequence but may recur throughout the composing process. It is also known as editing or post-writing stage.

Editing is mainly practiced in second language writing classes of engaging students in different activities that require correction of various language errors in their writing, such as errors in grammar, vocabulary, sentence structure and spelling. Grammar checker program is useful in checking certain grammatical and mechanics of writing such as the use of passive forms, concord, and punctuation. Some mechanics of writing such as spelling, use of apostrophes, hyphens, capitals, abbreviations and numbers, which are often dealt with in the revision or editing stages of writing. 'Revision' is intended to 'look again' at whole writing in order to improve organization, focus; and 'point of view' in writing is the position from which the writer presents an idea, for a good writing a consistent point of view is essential. There are many modes of writing. Essay writing has traditionally been classified into four kinds i.e. descriptive writing, narrative writing, expository writing and argumentative writing. Descriptive writing is involved with a verbal picture or account of a person, place or thing where as narrative writing is involved with telling the story of something that happened. Expository writing is another mode of writing in which explains a particular subject. Generally, the patterns of development 
within expository writing include describing a process of doing something, giving examples, analyzing causes and effects, comparing, contrasting, defining a concept and classifying it into categories.

There are many kinds of writing such as creative writing, cursive writing, quick writing, guided writing, idiographic writing, and expressive writing. There are also some approaches to writing according to kind of writing. Most prominent approaches to writing are process approach, product approach, expressive approach, genre approach etc. In any approach, outlining of piece of writing is useful. Outline presents the main points the piece of writing will cover and the order in which they will be mentioned. There are many kinds of outlines such as 'topic outline', 'sentence outline', and 'paragraph outline'. Macro-structure in writing is an overall organization of a text as compared with the details or microstructure of a passage. Creative writing includes some genres such as fiction, drama and poetry that reflect the writer's originality, imagination, feelings and which do not describe factual events where as cursive writing is a handwriting in which the letters within a word are joined, as compared with manuscript writing in which letter forms look like ordinary type and are unconnected within each word. 'Quick writing' in which students write as much as possible about a topic within a given time period without stopping. The goal is to produce as much writing as possible without worrying about grammar or accuracy, in order to develop fluency in writing and to produce ideas which might be used in a subsequent writing task. On the other hand, guided writing is a technique for teaching writing where the teacher provides detailed guidance in the form of questions, an outline, a model, or some other way of focusing and directing the students' writing. Another kind of writing, ideographic writing in which use of symbols to represent whole words or concepts or ideas is significant, for example Chinese writing system. A writer can express personal feelings, emotions, and experiences, in personal letters, diaries, or autobiographies using expressive writing.

\section{Conclusion}

It is concluded that there are many essential things that connected directly or indirectly to teaching and learning of English language to speakers of other languages. English language learning is involved with essential skills such as listening, speaking, reading and writing. There is a great need to follow various methods and approaches, use of various teaching and learning material, practising necessary activities and tasks are essentially useful. An effective use of various activities such as scaffolding to top-down in listening; role-plays to simulations for listening and speaking respectively. In the same way, an adept use of intensive reading and extensive reading; product approach, process approach in writing are certainly useful.

\section{REFERENCES}

[1] Johnson, Keith. Expertise in Second Language Learning and Teaching. Basingstoke, England: Palgrave Macmillan, 2005. Print.

[2] Hinkel, Eli. Handbook of Research in Second Language Teaching and Learning. Mahwah, N. J.: L. Erlbaum Associates 2005. Print.

[3] Macaro, Ernesto. Learning Strategies in Foreign and Second Language Classrooms. London: Continuum, 2001. Print.

[4] Randall, Mick. Memory, Psychology and Second Language Learning. Amsterdom: John Benjamins Pub., 2007. Print.

[5] Simhachalam, Thamarana and Narayana, T. "Significance of various Strategies for Teaching and Learning English." International Journal on Studies in English Language and Literature (2015): 75-79. Print.

[6] Stanford, Jeff, and Andrew Baker. Moodle 1.9 for Second Language Teaching Engaging Online Language-learning Activities Using the Moodle Platform. Birmingham, U. K.: Packet Pub., 2009. Print.

[7] Richards, Jack C., and Charles Lockhart. Reflective Teaching in Second Language Classrooms. Cambridge [England: Cambridge UP, 1994. Print.

[8] Hall, Joan Kelly. Second and Foreign Language Learning through Classroom Interaction. Mahwah, N.J.: Erlbaum, 2000. Print. 
[9] Krashen, Stephen D. Second Language Acquisition and Second Language Learning. Oxford: Pergamon, 1981. Print.

[10] Cook, Vivian. Second Language Learning and Language Teaching. $4^{\text {th }}$ ed. London: Arnold; 2008. Print.

[11] Mitchell, Rosamond, and Florence Myles. Second Language Learning Theories. $2^{\text {nd }}$ ed. London: Hodder Arnold, 2004. Print.

[12] Samuda, Virginia, and Martin Bygate. Tasks in Second Language Learning. Basingstoke: Palgrave Macmillian, 2008. Print. 